\title{
Communicative Socialism/Digital Socialism
}

\section{Christian Fuchs}

University of Westminster, London, christian.fuchs@uti.at, http://fuchs.uti.at

Abstract: This introduction provides a preface to the contributions gathered in tripleC's special issue "Communicative Socialism/Digital Socialism". It outlines how Marx conceived of socialism (Sections 2, 3, 4, 5), introduces a model of a socialist society that consists of three dimensions (Section 6), and shows how, based on Marx, we can conceptualise communicative and digital socialism (Section 7). Section 8 introduces ten principles of communicative/digital socialist politics.

Keywords: socialism, communication, digital, Karl Marx, communicative socialism, digital socialism, fully-automated luxury communism

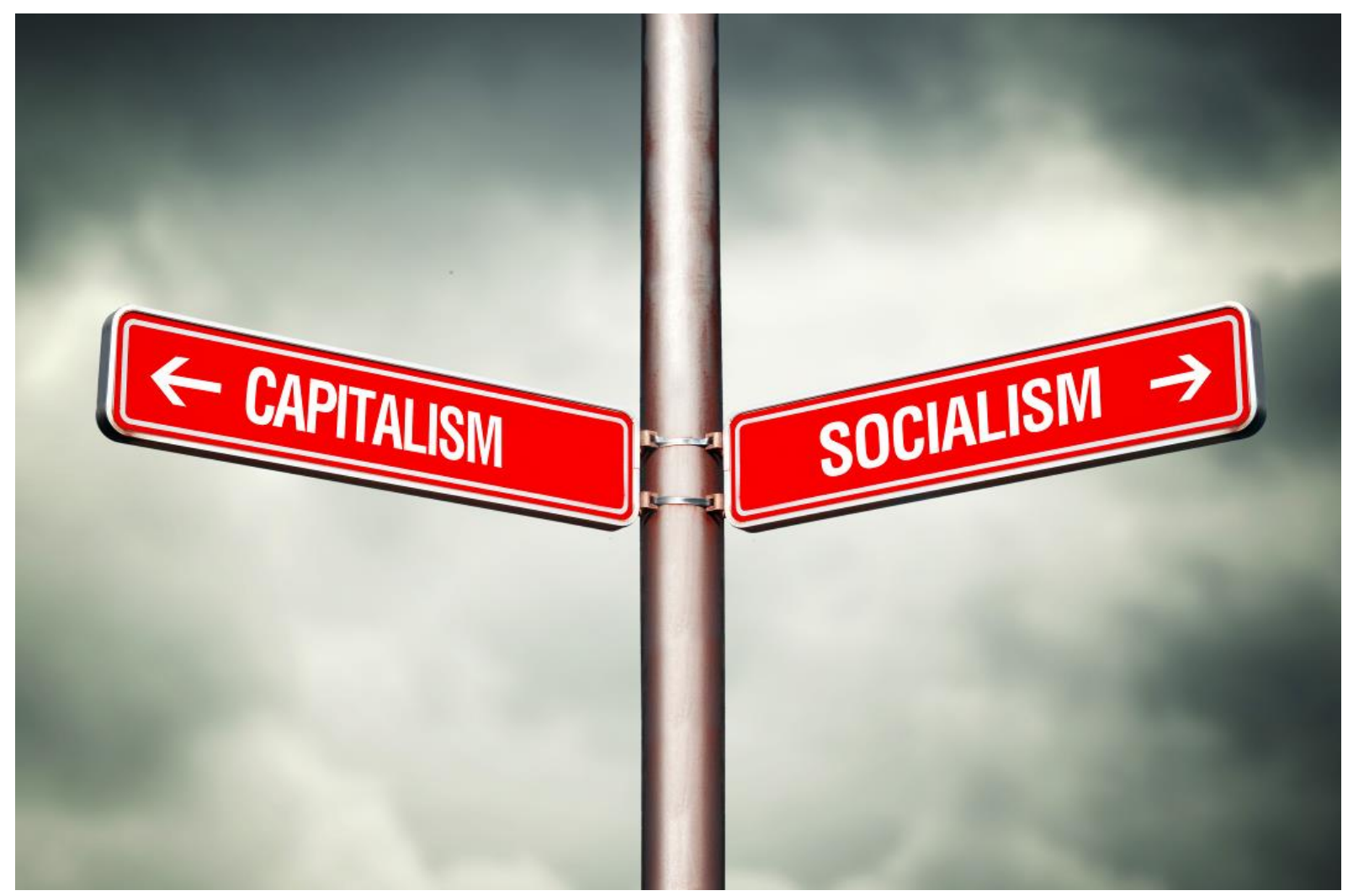

Image source: Shutterstock (enhanced licence)

\section{Introduction}

tripleC: Communication, Capitalism \& Critique's special issue "Communicative Socialism/Digital Socialism" asks: What is digital/communicative socialism? The special issue presents besides this general introduction 14 contributions that explore perspectives on digital and communicative socialism in respect to theory, dialectics, history, internationalism, praxis, and class struggles. 
Christopher $C$. Barnes analyses how socialists use social media. He presents results from an analysis of interviews conducted with members of the Democratic Socialists of America. The DSA has supported Bernie Sanders' presidential campaigns. Socialist senator Alexandria Orcasio-Cortez is a member of this political organisation. Barnes shows how socialists use social media to advance political stories, humour as politics, and media criticism, but also that they find aspects of social media use frustrating and alienating.

Dimitris Boucas analyses the theory, reality, and possibilities of digital and communicative socialism. He gives special attention to the theorisation of post-industrial socialism and the scientific and technological revolution in the works of Andre Gorz and Radovan Richta. The paper reports empirical results of research on how Internet alternatives could look like and discusses these results in the context of digital socialism.

Christopher M. Cox engages with the concept of fully automated communism/socialism that has become popular in recent times. The author stresses the importance of autonomy in the context of automation and reminds us that one needs to talk about both autonomous technology and autonomous humans.

Emiliana De Blasio and Michele Sorice analyse the role of digital technologies in the policies of contemporary socialist parties and movements. The analysis focuses on France, Italy, Portugal, Spain, and the USA. They show that work remains to be done in the establishment of a framework of practices that go beyond digital capitalism.

Donatella Della Ratta analyses the status of the social in and beyond communicative capitalism. She argues that user-generated spectacles, free labour, and capitalist realism on the Internet have brought about new forms of alienation and exploitation. She criticises the understandings of digital socialism advanced by Kevin Kelly, Daniel Saros, and Evgeny Morozov as ideological and suggests basing digital socialism on the ethics of care.

Nick Dyer-Witheford analyses left-wing responses to platform capitalism and in this context utilises Chantalle Mouffe's notion of left populism. He focuses specifically on left populism with respect to five topics: Internet speech and surveillance; the concentration of ownership of digital platforms; the regulation of working conditions in the gig economy; alternative models for the ownership of digital resources and platforms; and digital postcapitalism.

Sai Englert, Jamie Woodcock, and Callum Cant discuss aspects of what they call a digital Workerism. Inspired by Marx's and Italian Autonomist Marxism's method of the workers' inquiry, they ask how we can practice a similar method that fuses critical research and social struggles in the age of digital technologies .

Christian Fuchs discusses computing, communication, and communist utopias in the context of digital socialism in utopian literature, namely in William Morris' News From Nowhere, Peter Kroptokin's The Conquest of Bread, Ursula K. Le Guin's The Dispossessed, and P.M.'s bolo'bolo and Kartoffeln und Computer (Potatoes and Computers). The paper contributes to discussions about hi-tech communism and how to create a utopian, socialist Internet.

Hardy Hanappi argues that we live in the age of alienation. He outlines the development and consequences of the capitalist algorithm and how this algorithm has deepened the gap between the working class in and of itself to the point of the emergence of new forms of fascism and a Third World War. In this context, the contribution discusses the role of organic intellectuals for the development of socialist counterpower. 
Dmitry Kuznetsov and Milan Ismangil analyse the socialist YouTube-based video community Breadtube and discuss its political potentials for challenging right-wing ideology and capitalism. The analysis is focused on four major left-wing YouTube content creators - Contrapoints, Philosophy Tube, Shaun, and Hbomberguy.

Eleonora de Magalhães Carvalho, Afonso de Albuquerque, and Marcelo Alves dos Santos Jr analyse Brazil's socialist blogosphere in the dark times of Bolsonaro. Blogosfera Progressista (Progressive Blogosphere, hereafter BP) is a leftist political communication initiative. It aims at bringing together an institutional form of organisation with networked forms of politics, doing so at the time of, and opposed to, the far-right Bolsonaro regime.

Joan Pedro-Carañana analyses mediation in the works of the three Ibero-American critical theorists Jesús Martín-Barbero, Manuel Martín-Serrano, and Luis Martín-Santos in terms of contributions to the critique of digital capitalism and foundations of digital socialism.

Jamie Ranger discusses how we can slow down/decelerate social media as a constitutive aspect of digital socialism. He draws on and extends Hartmut Rosa's theory of speed and the notions of deceleration, acceleration, and hypermodulation, as well as critical theories of digital capitalism.

S. Harikrishnan analyses how the experience of the communist governance of the Indian state of Kerala has inspired and enabled the communication of communism. The focus is on the analysis of spaces (such as public spaces, libraries, reading rooms, tea-shops, cultural associations, forums, etc.) in the communication of communism, a development that the author analyses based on Lefebvre's critical theory of space.

Marx and Engels saw socialism as the movement for a society that is based on the principles of equality, justice, and solidarity. They also term such a society a socialist society and the movement struggling for it socialism. They distinguish different types of socialism, of which communism is one, while reactionary socialism, bourgeois socialism, and critical-utopian socialism are others. Marx and Engels argue that socialism is grounded in the antagonistic class structure of capitalism that pits workers against capitalists. In the 19th century, the socialist movement experienced a split between reformist revisionists and revolutionary socialists. After the First World War, the Communist International and the Labour and Socialist International were created. After the collapse of the Second International, there was an institutional distinction between Socialists and Communists. Whereas reformism dominated the Socialist International, Stalinism became dominant in the Communist International. The notion of 'socialism' became associated with social democratic parties and the notion of 'communism' with communist parties. From a historical point of view, both Stalinism and revisionist social democracy have failed.

With the rise of neoliberalism, social democracy turned towards the right and increasingly adopted neoliberal policies. When Tony Blair became British Prime Minster in 1997, his neoliberal version of social democracy influenced social democracy around the world. The crisis of capitalism and the emergence of new versions of socialist politics (Bernie Sanders, Jeremy Corbyn, Alexandria Ocasio-Cortez, Podemos, Syriza, etc.) has reinvigorated the debate about socialism today. Whereas the notion of communism is today still very often associated with Stalinism - though by the former term Marx did not mean terror and dictatorship, but the struggle for democracy (Marx and Engels 1848, 504) - there has been a new opening of and interest in the notion of socialism. 
triple $C$ 's special issue explores perspectives on the digital and communicative dimensions of socialism today. It presents contributions that address one or more of the following questions:

- Theory:

What is socialism today? What are the communicative and digital dimensions of socialism today? What is communicative/digital socialism? What theoretical approaches and concepts are best suited for understanding digital/communicative socialism today? Does it or does it not make sense to distinguish between digital/communicative socialism and digital/communicative communism? Why or why not?

- Dialectic:

What are the contradictions of digital capitalism? How does digital/communicative socialism differ from and contradict digital/communicative capitalism?

- History:

What lessons can we draw from the history of socialism, communism, social democracy and Marxist theory for the conceptualisation and praxis of digital/communicative socialism today?

- Internationalism:

Socialism is a universalist and internationalist movement. What are the international(ist), global dimensions of digital/communicative socialism today?

- Praxis and class struggles:

What strategies, demands and struggles are important for digital/communicative socialism? How can socialism today best be communicated in public? What class struggles are there around communication and computing? What is the role of communication and digital technologies in contemporary class struggles? What is the role of social movements, the party, and trade unions in the organisation and selforganisation of digital and communication workers' class struggles? What should class politics, unions and strikes look like today so that they adequately reflect changes of the working class and exploitation in the age of digital capitalism? What is a digital strike and what is its potential for digital socialism?

The remainder of this introduction focuses on a) how Marx conceived of socialism (Sections 2, 3, 4, 5); b) a model of a socialist society (Section 6); and c) how we can, based on Marx, conceptualise communicative and digital socialism (Section 7). Section 8 introduces ten principles of a communicative/digital socialist politics.

\section{Socialism and Communism}

Lenin (1917b, 472) argues that "the first phase of communist society" is "usually called socialism". Marx (1875) spoke of a first and second phase of communism. In the first phase, private property and capital cease to exist and the ownership of the means of production is socialised, but wage-labour, money, the state and exchange continue to exist. In the second phase, wages, wage-labour, money, the state, exchange-value and all forms of alienation cease to exist. But Marx did not call the first phase socialism and the second phase communism. He rather spoke of two stages or phases of communism. Communism is not just a type of society, but also a political movement.

In the Manifesto of the Communist Party, Marx and Engels (1848) speak of communism as a type of socialist movement. Besides communism they identify reactionary socialism, bourgeois socialism, and critical-utopian socialism as types of socialism. When one speaks of communism, one therefore means a type of socialism that aims at the abolition of class society and a democratic, worker-controlled economy within a participatory democracy. Given that Marx and Engels saw communism as a type of 
socialism, Marxists often use the terms socialism and communism interchangeably. Strictly speaking, socialism is broader than communism.

\subsection{Rosa Luxemburg on Socialism and Communism}

Rosa Luxemburg (1925, 141-144) clarifies the difference between socialism and communism:

Socialism goes back for thousands of years, as the ideal of a social order based on equality and the brotherhood of man, the ideal of a communistic society. With the first apostles of Christianity, various religious sects of the Middle Ages, and in the German peasants' war, the socialist idea always glistened as the most radical expression of rage against the existing society. [...] It was in the late eighteenth and early nineteenth century that the socialist idea first appeared with vigor and force, freed from religious enthusiasm, but rather as an opposition to the terror and devastation that emerging capitalism wreaked on society. Yet this socialism too was basically nothing but a dream, the invention of individual bold minds. [...] The socialist ideas represented by the three great thinkers: [Claude Henri] Saint-Simon and [Charles] Fourier in France, [Robert] Owen in England, in the 1820s and 30s, with far greater genius and brilliance, relied on quite different methods, but essentially rested on the same foundation. [...] $A$ new generation of socialist leaders emerged in the 1840s: [Wilhelm] Weitling in Germany, [Pierre Joseph] Proudhon, Louis Blanc and Blanqui in France. The working class, for its part, had already embarked on struggle against the rule of capital, it had given the signal for class struggle in the elemental insurrections of the Lyons silk weavers in France, and in the Chartist movement in England. But there was no direct connection between these spontaneous stirrings of exploited masses and the various socialist theories. [...] the socialist idea was placed on a completely new footing by Marx and Engels. These two sought the basis for socialism not in moral repugnance towards the existing social order nor in cooking up all kinds of possible attractive and seductive projects, designed to smuggle in social equality within the present state. They turned to the investigation of the economic relationships of present-day society.

Marx and Engels grounded socialism and the potentials of communism in the antagonistic class structure of capitalism that pits workers against capitalists. Marx saw the proletariat as the class that has the potential for "a revolutionary seizure of power for the realization of socialism" (Luxemburg 1925, 142).

\subsection{The Split of the Second International as Split Between Communism and Socialism}

In the 19th century, the socialist movement experienced a split between reformist revisionists and revolutionary socialists. On the one side, the revisionists believed in the evolutionary transition to socialism through victories in elections and an automatic breakdown of capitalism. On the other side, revolutionary socialists stressed the importance of class struggle, street action, mass political strikes, and fundamental transformations of society in order to establish a free society. In the Second International (1889-1916), the various factions of socialism were part of one organisation. The Second International collapsed during the First World War. Socialists were split between those who supported the War and those who radically opposed it.

After the First World War, the Communist International and the Labour and Socialist International were created. The latter was the forerunner of the Socialist International. 
After the collapse of the Second International, there was an institutional distinction between Socialists and Communists. Whereas reformism dominated the Socialist International, Stalinism became dominant in the Communist International. The notion of 'socialism' became associated with social democratic parties and the notion of 'communism' with communist parties. From a historical point of view, both Stalinism and revisionist social democracy have failed. Today it is time to stop strictly separating between communism and socialism, and instead to argue for a communist socialism as a radical, democratic socialism that aims at substituting capitalism by the democratic control of society, which includes workers' control of the economy, citizens' control of the political system, and human control of culture and everyday life. Marx saw communism as a radical, democratic movement and form of socialism.

Communism is "the rea/movement which abolishes the present state of things" and is grounded in "the now existing premise" of society, which means that it "presupposes the universal development of productive forces and the world intercourse bound up with them" (Marx and Engels 1845/1846, 49). Communism as "the abolition of private property" is a revolutionary social movement, the political "position as the negation of the negation" (Marx 1844, 306). For Marx, socialism is the positive movement or what Hegel terms the determinate negation (bestimmte Negation) that can follow the negation of the negation (Marx 1844, 305). This means that socialism is the society created by the communist movement on the basis, from the ruins, and as a transcendence of capitalism and class society.

For Marx and Engels, socialism is not an abstract idea, but has as its precondition the development of productive forces and the socialisation of work, is grounded in class antagonisms that it wants to overcome, and can only become real through class struggles that aim at abolishing class society and establishing a classless society. Socialism's conditions are class society's antagonisms, its method is communist class struggle, and its goal is a classless, socialist society. Society's productive forces are never independent from the social relations that organise how humans encounter each other and what type of society they live in. This means, for example, that the design, character, and use of technology depends on class and power relations that shape the character of society's structures and forces. Socialism is a sublation of the capitalist and class mode of the dialectic of the forces and relations of production so that a classless society based on the principles of equality, fairness, justice, solidarity, and cooperation emerges.

\subsection{Class-Struggle Social Democracy}

With the rise of neoliberalism, social democracy turned towards the right and increasingly adopted neoliberal policies. When Tony Blair became British Prime Minster in 1997 , his neoliberal version of social democracy influenced social democracy around the world. The consequence was that social democracy became in many respects indistinguishable from conservative parties, especially in respect to class politics. We need a left social democracy that struggles for democratic socialism. Rosa Luxemburg practiced a class struggle social democracy that struggled for radical reforms, and combined mass strikes and parliamentary action (see Luxemburg 2008). Luxemburg practiced dialectics of party/movements, organisation/spontaneity, intellectual leadership/masses.

Bhaskar Sunkara $(2019,215-237)$ argues for a new class-struggle social democracy that aims at winning elections and taking power; combines social movements, trade unions and the party; realises transitional policies that move society "quickly from social democracy to democratic socialism" (Sunkara 2019, 221); acknowledges the 
changes of the working class; embeds itself in working class struggles; and struggles for "dignity, respect, and a fair shot at the good life" through universalist, "democratic class politics" that unite individuals "against our common opponent and win the type of change that will help the most marginalized, all while engaging in a far longer campaign against oppression rooted in race, gender, sexuality, and more" $(2019,236)$.

Michael Hardt and Antonio Negri (2017) term the convergence of unions and social movements "social unionism" (social movements plus unions). Social unionism organises social strikes that take place in a society that has become a factory at large. Social unions entail "organizing new social combinations, inventing new forms of social cooperation, generating democratic mechanisms for our access to, use of, and participation in decision-making about the common" (2017, xix). Hardt and Negri argue for the complementarity of the three political strategies: "The taking of power, by electoral or other means, must serve to open space for autonomous and prefigurative practices on an ever-larger scale and nourish the slow transformation of institutions, which must continue over the long term. Similarly practices of exodus must find ways to complement and further projects of both antagonistic reform and taking power" (278). Example projects that such a complementary left-wing politics could struggle for include guaranteed basic income as "a money of the common" and "open access to and democratic management of the common" (294).

Class struggle social democracy struggles for communism as a democratic socialist society by practicing dialectics of reform/revolution (radical reformism), party/movement (movement parties), organisation/spontaneity (organised spontaneity), and working class politics/societal politics (social working class politics).

We will discuss aspects of socialism along three lines: the economy (Section 3), politics (Section 4), and culture (Section 5). Communism is a democratic society that is based on equality, justice, fairness, solidarity, wealth and luxury for all, and participatory democracy.

\section{The Socialist Economy}

\subsection{Common Ownership}

A key characteristic of a socialist society is that the means of production are the common property of the producers: "In this sense, the theory of the Communists may be summed up in the single sentence: Abolition of private property. [...] When, therefore, capital is converted into common property, into the property of all members of society, personal property is not thereby transformed into social property. It is only the social character of the property that is changed. It loses its class character" (Marx and Engels $1848,498 ; 499)$. For Marx, "communism is humanism mediated with itself through the supersession of private property" (Marx 1844, 341).

\subsection{Production and Labour}

Toil is for Marx and Engels incompatible with a socialist society. They see the reduction of necessary labour and the abolition of hard labour as an important aspect of socialism: "The realm of freedom really begins only where labour determined by necessity and external expediency ends; [...] The reduction of the working day is the basic prerequisite" (Marx 1894, 958-959). Therefore, a communist society is only possible as a high-tech society that has a high level of productivity.

What is the aim of the Communists? Answer: To organise society in such a way that every member of it can develop and use all his capabilities and powers in 
complete freedom and without thereby infringing the basic conditions of this society (Engels 1847a, 96).

[In communism] nobody has one exclusive sphere of activity but each can become accomplished in any branch he wishes, society regulates the general production and thus makes it possible for me to do one thing today and another tomorrow, to hunt in the morning, fish in the afternoon, rear cattle in the evening, criticise after dinner, just as I have a mind, without ever becoming hunter, fisherman, shepherd or critic (Marx and Engels 1845/1846, 47).

In a high-tech socialist society, where the division of labour is abolished, humans are enabled to freely choose their work activities and to be active as well-rounded individuals who engage in many different activities. This means that humans can freely use their capabilities. Labour turns into free activity without a struggle for survival and coercion by the market.

In a socialist society, production takes place based on the principle of human need and not based on the principle of profit (the need of capital). This requires some form of planning of production:

In communist society, where the interests of individuals are not opposed to one another but, on the contrary, are united, competition is eliminated. [...] In communist society it will be easy to be informed about both production and consumption. Since we know how much, on the average, a person needs, it is easy to calculate how much is needed by a given number of individuals, and since production is no longer in the hands of private producers but in those of the community and its administrative bodies, it is a trifling matter to regulate production according to needs (Engels 1845a, 96).

Part of the reason state communism failed was that the central planning of human needs and the economy failed. Economies are complex and have unpredictable features. Economic planning needs to be decentralised, which in a networked and computerised society can take on the form of a decentralised collection of the goods that individuals and households require. This information can then be sent to production units that thereby know how many goods are required during a certain period of time. Networking of production within industrial sectors enables the comparison of the available production capacities and productivity levels, which enables the production of the right amount of goods.

For Marx and Engels, socialism includes a democratic economy, in which the workers own the means of production in common. In such self-managed companies, decisions are taken in common:

Above all, it will have to take the running of industry and all branches of production in general out of the hands of separate individuals competing with each other and instead will have to ensure that all these branches of production are run by society as a whole, i.e., for the social good, according to a social plan and with the participation of all members of society. It will therefore do away with competition and replace it by association. [...] private ownership will also have to be abolished, and in its stead there will be common use of all the instruments of production and the distribution of all products by common agreement, or the so-called community of property. The abolition of private ownership is indeed the most succinct and characteristic summary of the transformation of the entire 
social system necessarily following from the development of industry, and it is therefore rightly put forward by the Communists as their main demand (Engels 1847b, 348).

\subsection{Circulation, Distribution and Consumption}

Marx argues that a socialist society must reuse parts of the social product as means of production, whereas the other parts constitute means of consumption that need to be distributed among the individuals:

Let us finally imagine, for a change, an association of free men, working with the means of production held in common, and expending their many different forms of labour-power in full self-awareness as one single social labour force. [...] The total product of our imagined association is a social product. One part of this product serves as fresh means of production and remains social. But another part is consumed by the members of the association as means of subsistence. This part must therefore be divided amongst them (Marx 1867, 172173).

Marx and Engels distinguish between two phases of a socialist society: crude communism as the first stage and fully developed communism as the second stage. In the first stage, there is the elimination of capital, profit and the private property of the means of production, but not necessarily the abolition of wage-labour, money, exchange, and commodities. The means of production are collectively owned, but the productive forces are not yet developed to the stage that allows the abolishment of necessary labour.

The first stage of communism has not "developed on its own foundations", but develops "just as it emerges from capitalist society, which is thus in every respect, economically, morally and intellectually, still stamped with the birth-marks of the old society from whose womb it emerges" (Marx 1875, 85). In the first stage of communism, "the community is simply a community of labour, and equality of wages paid out by communal capital - by the community as universal capitalist" (Marx 1844, 295). A "given amount of labour in one form is exchanged for an equal amount of labour in another form. [...] The right of the producers is proportional to the labour they supply; [...] It recognises no class distinctions, because everyone is only a worker like everyone else" (Marx 1875, 86, emphasis in original). Marx writes elsewhere that in communism, money would immediately disappear: "If we were to consider a communist society in place of a capitalist one, then money capital would immediately be done away with, and so too the disguises that transactions acquire through it" $(1885,390)$. The implication is that there might be versions of lower-stage communism with and without money.

In the higher, fully developed form of communism, the means of production are highly developed so that necessary labour and exchange are abolished:

In a higher phase of communist society, after the enslaving subordination of the individual to the division of labour, and thereby also the antithesis between mental and physical labour, has vanished; after labour has become not only a means of life but life's prime want; after the productive forces have also increased with the all-round development of the individual, and all the springs of common wealth flow more abundantly - only then can the narrow horizon of bourgeois right be crossed in its entirety and society inscribe on its banners: From each according to his abilities, to each according to his needs! (Marx 1875, 87). 
"From each according to their abilities, to each according to their needs" is a central communist principle. In a fully developed communist society, there is no wage-labour and no compulsion to work. Everyone works as far as he can and work is largely selffulfilment. Goods are not sold or exchanged, but given to humans freely as gifts. There is distribution not according to the possession of money, but according to human needs.

\section{Socialist Politics}

Communism as the positive transcendence of private property as human selfestrangement, and therefore as the real appropriation of the human essence by and for man; communism therefore as the complete return of man to himself as a social (i. e., human) being - a return accomplished consciously and embracing the entire wealth of previous development (Marx 1844, 296, emphasis in original).

Freedom is an important principle of democratic societies. For Marx, socialism means the abolition of alienation and the realisation of true freedom that allows humans to fully develop their potentials. A socialist society is a democracy and a humanism, in which the freedom of all interacts with individual freedom. "In place of the old bourgeois society, with its classes and class antagonisms, we shall have an association, in which the free development of each is the condition for the free development of all" (Marx and Engels 1848, 506).

It has often been argued that communism/socialism is totalitarian. But for Marx and Engels, democracy is a precondition of socialism. This circumstance becomes, for example, very clear in the following passages:

Question 18: What will be the course of this revolution? Answer: In the first place it will inaugurate a democratic constitution and thereby, directly or indirectly, the political rule of the proletariat (Engels 1847b, 350).

Democracy nowadays is communism. [...] Democracy has become the proletarian principle, the principle of the masses. The masses may be more or less clear about this, the only correct meaning of democracy, but all have at least an obscure feeling that social equality of rights is implicit in democracy. The democratic masses can be safely included in any calculation of the strength of the communist forces. And if the proletarian parties of the different nations unite they will be quite right to inscribe the word 'Democracy' on their banners, since, except for those who do not count, all European democrats in 1846 are more or less Communists at heart (Engels 1845b, 5).

Marx and Engels argue that communists do not oppose reforms, but argue for progressive and radical reforms that reduce the power of capital and forces that support domination.

Democracy would be quite useless to the proletariat if it were not immediately used as a means of carrying through further measures directly attacking private ownership and securing the means of subsistence of the proletariat. [...] Once the first radical onslaught upon private ownership has been made, the proletariat will see itself compelled to go always further, to concentrate all capital, all agriculture, all industry, all transport, and all exchange more and more in the hands 
of the State. [...] Finally, when all capital, all production, and all exchange are concentrated in the hands of the nation, private ownership will automatically have ceased to exist, money will have become superfluous, and production will have so increased and men will be so much changed that the last forms of the old social relations will also be able to fall away (Engels 1847b, 351).

Progressive politics that socialists support include, for example, a "heavy progressive or graduated income tax", the "[e]xtension of factories and instruments of production owned by the State", the "[c]ombination of agriculture with manufacturing industries; the "gradual abolition of all the distinction between town and country by a more equable distribution of the populace over the country", or the "[f]ree education for all children in public schools" (Marx and Engels 1848, 505).

\section{Socialist Culture}

\subsection{Togetherness}

A socialist society also changes social relations in the realm of culture. Whereas capitalist culture through the logic of commodity consumption advances a culture of isolation and individualisation focused on the individual consumption of commodities and the competition for reputation, socialist culture means the development of a common culture, where humans associate and produce and consume culture together:

When communist artisans associate with one another, theory, propaganda, etc., is their first end. But at the same time, as a result of this association, they acquire a new need - the need for society - and what appears as a means becomes an end. In this practical process the most splendid results are to be observed whenever French socialist workers are seen together. Such things as smoking, drinking, eating, etc., are no longer means of contact or means that bring them together. Association, society and conversation, which again has association as its end, are enough for them; the brotherhood of man is no mere phrase with them, but a fact of life, and the nobility of man shines upon us from their workhardened bodies (Marx 1844, 313).

\subsection{The Family}

Socialist society also changes personal relations and the family. It reduces the dependence and power relations within the family and thereby advances equality:

What influence will the communist order of society have upon the family? Answer: It will make the relation between the sexes a purely private relation which concerns only the persons involved, and in which society has no call to interfere. It is able to do this because it abolishes private property and educates children communally, thus destroying the twin foundation of hitherto existing marriage the dependence through private property of the wife upon the husband and of the children upon the parents (Engels 1847b, 354).

\subsection{Internationalism}

Socialist culture is inherently internationalist. All humans are seen as members of the global family of humanity. There is no place for the nation and nationalism in a socialist society. Humans have commonalities and differences. A socialist society advances a 
culture that is based on global unity in diversity, a dialectic of common culture and differentiated lifestyles and norms.

The working men have no country. We cannot take from them what they have not got. Since the proletariat must first of all acquire political supremacy, must rise to be the leading class of the nation, must constitute itself the nation, it is so far, itself national, though not in the bourgeois sense of the word (Marx and Engels 1848, 503-504).

Will nationalities continue to exist under communism? Answer: The nationalities of the peoples who join together according to the principle of community will be just as much compelled by this union to merge with one another and thereby supersede themselves as the various differences between estates and classes disappear through the superseding of their basis - private property (Engels 1847a, 103).

\section{A Model of Socialism}

For Marx (1844, 296), communism as revolutionary socialism is the "reintegration or return of man to himself, the transcendence of human self-estrangement", "the real appropriation of the human essence", "fully developed humanism".

The human being is a socially producing being that produces its livelihood, which includes use-values (economy), collective decisions governing life (politics), and meanings that define life's purpose (culture). Given that alienation goes for Marx beyond the economy and covers all realms of human production and life, including the economy and culture, Marx does not limit the notion of socialism to the economy, but sees it as the full development of humanism in society. Marx says that "abolition of private property and communism are by no means identical" (Marx 1843, 143) and therefore stresses that socialism means "the abolition of class distinctions generally" together with "all the relations of production on which they rest", including all corresponding "social relations" and "all the ideas that result from these social relations" (Marx 1850, 127, emphasis in original).

Axel Honneth $(2017,106)$ stresses that socialism means the application "of the notion of social freedom to all three constitutive spheres of modern societies (not just the economy, but also politics and personal relationships)": "Only if all members of society can satisfy the needs they share with all others - physical and emotional intimacy, economic independence and political self-determination - by relying on the sympathy and support of their partners in interaction will our society have become social in the full sense of the term" (107-108).

First, we need to add that Marx, as just argued, already saw socialism as a society, where freedom, solidarity and co-operation operate in the realms of the economy, politics, and culture. Second, Honneth's third realm is restricted to the personal relationships of "the family and intimate relationships" $(2017,107)$. The realm of meaningmaking in everyday life is much wider than this and, besides the family, includes: friendships, love and sexuality; aspects of life such as education, worldviews, religion, philosophy, science, morality, sports, entertainment, consumption, care, arts, health and medicine; or life and death. Third, society's three realms (economy, politics, culture) are neither independent nor simply interdependent, but are all realms of social production that constitutes society's materiality. Politics and culture are at the same time economic (realms of the production of collective decisions and meanings) and non-economic (Fuchs 2020a [Chapter 3], 2020b [Chapters 2 and 3]; 2017; 2016). 
There are three dimensions of a socialist society: the socialist economy, socialist politics, and socialist culture. Whereas in an alienated, dominative, heteronomous class society, the three spheres of society are ruled by instrumental reason and particularistic interests, the three realms are in a socialist society shaped by co-operative reason and the common interest. Socialist society is organised in ways that benefit all. In class society, society only benefits some, and at the expense of others. Table 1 contrasts alienated society with socialist society. It shows three dimensions of socialism that are sublations of alienation.

\begin{tabular}{|l|l|l|}
\hline & Alienated society & Socialist society \\
\hline Economy & Class & $\begin{array}{l}\text { Common, socialist economy: } \\
\text { collective ownership of the means of pro- } \\
\text { duction, abolition of toil and necessary la- } \\
\text { bour, well-rounded individuality with free } \\
\text { work, self-managed companies, production } \\
\text { from each according to their abilities, distri- } \\
\text { bution to each according to their needs, } \\
\text { wealth for all }\end{array}$ \\
\hline Politics & Dictatorship & Common politics: participatory democracy \\
\hline Culture & Ideology, disrespect & $\begin{array}{l}\text { Common culture: internationalism, culture of } \\
\text { unity in diversity, self-realisation of all hu- } \\
\text { mans }\end{array}$ \\
\hline
\end{tabular}

Table 1: Three dimensions of socialist society and their opposition to alienated society

The common, socialist economy is the sublation of class society. The common politics of participatory democracy is the sublation of dictatorship. Common culture is the sublation of ideology and disrespect. Production in society is a dialectic of objects/human subjects that results in the creation of products. Table 2 shows how these dimensions look in a socialist society with respect to the three dimensions of society.

\begin{tabular}{|l|l|l|l|}
\hline Type & Subjects & Object & Products \\
\hline $\begin{array}{l}\text { Economic } \\
\text { socialism }\end{array}$ & $\begin{array}{l}\text { Commoners, } \\
\text { well-rounded } \\
\text { individuals }\end{array}$ & $\begin{array}{l}\text { Collectively owned } \\
\text { means of produc- } \\
\text { tion, self-managed } \\
\text { companies }\end{array}$ & $\begin{array}{l}\text { Common goods, } \\
\text { wealth for all, self-ful- } \\
\text { filment for all }\end{array}$ \\
\hline $\begin{array}{l}\text { Political so- } \\
\text { cialism }\end{array}$ & Democrats & $\begin{array}{l}\text { Participatory de- } \\
\text { mocracy }\end{array}$ & $\begin{array}{l}\text { Common decisions } \\
\text { and rights }\end{array}$ \\
\hline $\begin{array}{l}\text { Cultural so- } \\
\text { cialism }\end{array}$ & Friends & $\begin{array}{l}\text { Shared meanings } \\
\text { and knowledge }\end{array}$ & $\begin{array}{l}\text { Common, internation- } \\
\text { alist culture of unity in } \\
\text { diversity, recognition } \\
\text { and voice for all }\end{array}$ \\
\hline
\end{tabular}

Table 2: Subjects, objects and products in the three realms of socialist society

Erich Fromm shows that Marx saw economic democracy beyond necessity, political democracy and creative self-realisation as the three dimensions of socialism:

In socialism, the human being "produces in an associated, not competitive way; he produces rationally and in an unalienated way, which means that he brings 
production under his control, instead of being ruled by it as by some blind power. [...] [Socialism] means, in short, the realization of political and industrial democracy. Marx expected that by this new form of an unalienated society man would become independent, stand on his own feet, and would no longer be crippled by the alienated mode of production and consumption; that he would truly be the master and the creator of his life, and hence that he could begin to make living his main business, rather than producing the means for living. Socialism, for Marx, was never as such the fulfillment of life, but the condition for such fulfillment. [...] Man, in Marx's view, has created in the course of history a culture which he will be free to make his own when he is freed from the chains, not only of economic poverty, but of the spiritual poverty created by alienation. Marx's vision is based on his faith in man, in the inherent and real potentialities of the essence of man which have developed in history. He looked at socialism as the condition of human freedom and creativity, not as in itself constituting the goal of man's life. [...]

Socialism, for Marx, is a society which serves the needs of man. [...] Marxist and other forms of socialism are the heirs of prophetic Messianism, Christian Chiliastic sectarianism, thirteenth-century Thomism, Renaissance Utopianism, and eighteenth-century enlightenment. It is the synthesis of the prophetic-Christian idea of society as the plane of spiritual realization, and of the idea of individual freedom. For this reason, it is opposed to the Church because of its restriction of the mind, and to liberalism because of its separation of society and moral values. It is opposed to Stalinism and Krushchevism, for their authoritarianism as much as their neglect of humanist values.

Socialism is the abolition of human self-alienation, the return of man as a real human being. [...] For Marx, socialism meant the social order which permits the return of man to himself, the identity between existence and essence, the overcoming of the separateness and antagonism between subject and object, the humanization of nature; it meant a world in which man is no longer a stranger among strangers, but is in his world, where he is at home" (Fromm 1961/2003, $50 ; 51 ; 55 ; 56)$.

Discussions about socialism in the 21st century have foregrounded the commons. The basic argument is that neoliberal capitalism has resulted in the commodification and privatisation of common goods that are either produced by all humans or that all humans need in order to exist. ${ }^{1}$

Slavoj Žižek $(2010,212-213)$ distinguishes between the cultural commons (language, means of communication, education, infrastructures), the commons of external nature (the natural environment), and the commons of internal nature (human subjectivity, our bodies and minds).

Michael Hardt and Antonio Negri $(2017,166)$ argue that there are two major forms of the commons: the social and the natural commons. These forms are divided into five subtypes: the earth and its ecosystems; the "immaterial" common of ideas, codes, images and cultural products; physical goods produced by co-operative work; metropolitan and rural spaces that are realms of communication, cultural interaction and cooperation; and social institutions and services that organise housing, welfare, health, and education $(2017,166)$. For Hardt and Negri, contemporary capitalism's class structure features the extraction of the commons, which includes the extraction of natural

\footnotetext{
1 See: Douzinas and Žižek (2010); Žižek (2013); Žižek and Taek-Gwang Lee (2016); Ali (2009);
} Badiou (2015); Dean (2012); Hardt and Negri (2009). 
resources; data mining/data extraction; the extraction of the social from the urban spaces on real estate markets; and finance as extractive industry (166-171).

The advantage of such understandings of the commons is that they allow a popular critique of neoliberal capitalism and its undermining of the welfare state, nature, and cultural institutions such as the education system and hospitals. They also stress that the commons advance communist potentials from within the contradictions of capitalism, a "communism of capital". 2 This perspective allows the reinvention of communism in the 21st century as commonism, a politics that struggles against the dispossession, privatisation, commodification and financialisation of the commons. But at the same time, the discussed definitions of the commons are not fully in line with Marx and Engels' understanding of the commons as "common property, [...] the property of all members of society" (Marx and Engels 1848, 499) that is governed by "common agreement" (Engels 1847b, 348). All economic, political and cultural goods and structures can be turned into common goods that are controlled by all those who are affected by them. Tables 1 and 2 are based on this understanding of the commons as common economy, common politics, and common culture.

\section{Communicative/Digital Socialism}

\subsection{Socialism and Technology}

\subsubsection{The Antagonism of Productive Forces and Relations of Production}

Capitalism is based on an antagonism between productive forces and the relations of production. Capitalist technology socialises labour; that is, it brings about new forms of co-operation and potentials for collective ownership, new common goods (such as the digital commons) and the reduction of necessary labour time: these are communist potentials, or what some term the communism of capital. Digital capitalism creates new forms and technologies of co-operation that are foundations of new common goods. But such forms and technologies are within class relations and capitalist means of exploitation and domination, and potentially common goods are often subsumed under the commodity form, class relations, and capital. In capitalism, new communist potentials cannot fully develop and technological development advances social antagonisms such as the rise of precarious labour and life. Marx and Engels describe this antagonism in the following manner:

The productive forces at the disposal of society no longer tend to further the development of the conditions of bourgeois property; on the contrary, they have become too powerful for these conditions, by which they are fettered, and so soon as they overcome these fetters, they bring disorder into the whole of bourgeois society, endanger the existence of bourgeois property. The conditions of bourgeois society are too narrow to comprise the wealth created by them. And how does the bourgeoisie get over these crises? On the one hand by enforced destruction of a mass of productive forces; on the other, by the conquest of new markets, and by the more thorough exploitation of the old ones. That is to say, by paving the way for more extensive and more destructive crises, and by diminishing the means whereby crises are prevented (Marx and Engels 1848, 490).

2 See: Virno (2004, 110-111), Marazzi (2010), Bauwens and Kostakis (2014), Beverungen, Murtola and Schwartz (2013), Dyer-Witheford (2014), Lund (2017, 76-81, 298-328). 
In Capital Volume 1, Chapter 32, Marx formulates the antagonism between productive forces and relations of production in the following way: "At a certain stage of development, [the capitalist mode of production] brings into the world the material means of its own destruction. From that moment, new forces and new passions spring up in the bosom of society, forces and passions which feel themselves to be fettered by that society" (Marx 1867, 928).

In the 21st century, information technology and the Internet are founded on an antagonism of class relations and the now networked productive forces. A good example is that the Internet allows the free sharing of information via peer-to-peer platforms and other technologies, which on the one hand questions the capitalist character of culture and so makes the music and film industry nervous, but on the other hand within capitalism can also constitute problems for artists who depend on deriving income from cultural commodities. Informational networks aggravate the capitalist antagonism between the collective production and the individual appropriation of goods and the antagonism between productive forces and relations of production. Productive forces that are tied up by existing relations do not necessarily or automatically fully develop. It is in no way assured that they can be freed. They can remain enchained and will remain enchained as long as individuals enchain themselves. Networks are a material condition of a free association, but the cooperative networking of the relations of production is not an automatic result of networked productive forces.

\subsubsection{The Antagonism Between Productive Forces and Relations of Production in the Grundrisse's "Fragment on Machines"}

Marx shows in the Grundrisse's "Fragment on Machines" how modern technology reduces necessary labour time - the annual labour-time a society needs in order to survive - and thereby creates conditions for a socialist society, free individuality, and a life based on free time as a source of wealth, but at the same time is embedded into capitalist class relations that have to set labour-time as the source of wealth so that the antagonism between the ever-more-socialised productive forces and the relations of production deepens the enslavement of labour; unemployment; precarity, and the crisis-proneness of capitalism. The capitalist antagonism between productive forces and relations of production is an antagonism between necessary labour (that technology ever more reduces) and surplus labour (that capital tries to ever more increase):

Under the conditions of capitalist technology, the worker "steps to the side of the production process instead of being its chief actor. [...] as the great foundationstone of production and of wealth. The theft of alien labour time, on which the present wealth is based, appears a miserable foundation in face of this new one, created by large-scale industry itself. As soon as labour in the direct form has ceased to be the great well-spring of wealth, labour time ceases and must cease to be its measure, and hence exchange value [must cease to be the measure] of use value. The surplus labour of the mass has ceased to be the condition for the development of general wealth, just as the non-labour of the few, for the development of the general powers of the human head. With that, production based on exchange value breaks down, and the direct, material production process is stripped of the form of penury and antithesis. The free development of individualities, and hence not the reduction of necessary labour time so as to posit surplus labour, but rather the general reduction of the necessary labour of society to a minimum, which then corresponds to the artistic, scientific etc. development of 
the individuals in the time set free, and with the means created, for all of them (Marx 1857/1858, 705-706).

\subsubsection{Technology and Time in Capitalism and Socialist Society}

Marx ascertains a capitalist antagonism between the tendency of technology to reduce necessary labour time and the capitalist tendency to turn all labour time into surplus labour and argues that modern technology creates the foundation of a socialist society, in which free time and free activity beyond necessity is maximised and the source of wealth:

[Capital] increases the surplus labour time of the mass by all the means of art and science [...] It is thus, despite itself, instrumental in creating the means of social disposable time, in order to reduce labour time for the whole society to a diminishing minimum, and thus to free everyone's time for their own development. But its tendency always, on the one side, to create disposable time, on the other, to convert it into surplus labour. If it succeeds too well at the first, then it suffers from surplus production, and then necessary labour is interrupted, because no surplus labour can be realized by capital. The more this contradiction develops, the more does it become evident that the growth of the forces of production can no longer be bound up with the appropriation of alien labour, but that the mass of workers must themselves appropriate their own surplus labour. Once they have done so - and disposable time thereby ceases to have an antithetical existence - then, on one side, necessary labour time will be measured by the needs of the social individual, and, on the other, the development of the power of social production will grow so rapidly that, even though production is now calculated for the wealth of all, disposable time will grow for all. For real wealth is the developed productive power of all individuals. The measure of wealth is then not any longer, in any way, labour time, but rather disposable time (Marx 1857/1858, 708).

Marx adds that "[r]eal economy [...] consists of the saving of labour time" so that there can be "an increase of free time, i.e. time for the full development of the individual" $(1857 / 1858,711)$. Marx ascertains in the Grundrisse that a socialist society requires a technological foundation so that society can be based on the principle "From each according to his abilities, to each according to his needs!". Socialism is only possible as a computerised, high-technology, post-scarcity society that creates wealth and luxury for all.

Roman Rosdolsky (1977, 427-428) comments in his study of the Grundrisse on the importance of the technological foundations of socialism:

It is hardly necessary today - in the course of a new industrial revolution - to emphasise the prophetic significance of this enormously dynamic and essentially optimistic conception. For the dreams of the isolated German revolutionary in his exile in London in 1858 have now, for the first time, entered the realm of what is immediately possible. Today, for the first time in history, thanks to the developments of modern technology, the preconditions for a final and complete abolition of the 'theft of alien labour-time' actually exist; furthermore, the present period is the first in which the development of the productive forces can be carried so far forward that, in fact, in the not too distant future it will be not labour-time, but rather disposable time, by which social wealth is measured (Rosdolsky 1977, 427-428). 


\subsubsection{Fully Automated Luxury Communism?}

Aaron Bastani (2019) argues in his book Fully Automated Luxury Communism that new technologies such as information technology ("the defining feature of the Third Disruption" - by which he means a third technological revolution in the history of humankind - "is ever-greater abundance in information" $(2019,37)$; that Al-based automation, green energy technologies, space travel, 3D printing, gene therapy and editing, and synthetic food such as cultured meat will soon enable humans to overcome scarcity and to thereby create an abundance of free time, energy, space, health, and sustainable artificial food. He sees these technologies as the foundation of fully automated luxury communism, where "work is eliminated, scarcity replaced by abundance and where labour and leisure blend into one another" (50). Fully automated luxury communism is a "realm of plenty" (54) with "luxury for all" (192) and everything for all.

Bastani rightly reiterates Marx's insight that communism requires material and technological foundations and can therefore only be a high-tech communism. His version of technological analysis avoids technological determinism because he is aware that communism does not automatically emerge from technology, but rather requires political-economic transformations. The book's analysis is a techno-optimism without technological determinism. But such optimism is a new, 21st-century form of utopian socialism because it underestimates how capitalism results in the design of negative and destructive potentials into contemporary technologies. For Bastani, there are only positive potentials of technology and he seems to think that when communism comes, the same technologies can be used without humans having to transform and redesign many of them and having to abolish at least some of them. He also underestimates that technologies are complex systems which can in any society have unpredictable, negative consequences. Bastani's technological analysis confers the image of a perfectly controllable technology. When he writes that "resources, energy, health, labour and food - just like information - want to be free" $(2019,216)$, he overlooks that only humans and not resources act and have interests. Freedom as want is a human want and interest that cannot be reduced to technology.

Automated technologies can involve programming or system errors that result in serious accidents and disasters. Space exploration is a part of geopolitical and military rivalries. Even in a communist society that is relatively peaceful, massive resource investments into space exploration may result in a lack of resources available for welfare. $3 \mathrm{D}$ home printing could result in the production of a massive amount of non-recyclable consumer goods that pose an environmental problem. Genetic engineering can cause new diseases and risks to health and life. The mass production of cultured meat could create unforeseen risks that do not make it clean meat, but rather dirty meat. Operating a vast number of labs for producing cultured meat could increase the world's energy use. If a transition to renewable energy has at the same time not been achieved, total carbon dioxide emissions could increase. Communism is likely to reduce the risks of technologies that stem from cost cutting and profit imperatives, but collective ownership and non-profit production oriented on use-value is no panacea for the potential risks new technologies pose. A communist society requires prospective, critical technology assessment and communist tech ethics and tech policies that regulate new technologies. Technology is not just an economic issue, but also has political and cultural dimensions that are based on but not reducible to the economy.

It is questionable that there can be 'full' automation. Automation will always have to remain under human control and can never fully replace humans. For society to exist, technologies and societies need to be built, repaired, morally judged and assessed, which only humans can do. And there are forms of human work, such as social 
care and education, whose automation is morally undesirable if we want to exist in a humane society built on the principle of communist love. A posthuman technology without any human work would result in the technologically-induced breakdown of society, because once robots that repair robots encounter a system error or a power outage, humans have to step in. Posthuman ideology overestimates the capacities of technologies to automate human subjectivity. No robot will ever understand what love is. Therefore a robot cannot practice love. You cannot automate love. And artificial imitations of love are nothing more than cheap fakes. Communism requires technological foundations, but high tech alone is not enough. Communism's guiding principle is neither technology nor love of technology, but love.

Bastani advances a form of posthumanist communism. He does not give much attention to Marx's concept of well-rounded individuality in a communist society. One reason why work understood as the creation of use-values will not stop is that humans have a desire for self-fulfilment and creativity whose potentials cannot be fully realised in a class society. In a communist society, humans would be too bored if they sat on the couch all day watching television. They would engage in a multitude of social and productive activities, free from necessity and compulsion. For Bastani (2019), luxury populism is the opposite of neoliberal politics (185-200). But he leaves open whether or not, in his view, the nation continues to exist in communist society. He argues for internationalism and not for an alternative form of globalisation. The nation is an artificial, ideological construct. Populism does not appeal to the working class, but to a people. It is therefore mostly based on nationalism (Fuchs 2020c). But Marx and Engels knew that communism requires as its political foundation global solidarity. Communism needs working class politics that liberates humanity from class, capital, labour, toil, pollution, destruction, war, necessity, and so on.

It is encouraging that there is a new interest in the role of technology in communism and understanding communism as wealth and luxury for all. But such discoveries in themselves are nothing new.

In his 1892 manifesto The Conquest of Bread, Peter Kropotkin wrote about wealth and luxury for all in a communist society: "What is now the privilege of an insignificant minority would be accessible to all. Luxury, ceasing to be a foolish and ostentatious display of the bourgeois class, would become an artistic pleasure" (Kropotkin $1892 / 2012$, 106). Kropotkin clearly built on Marx's insights and therefore argued that luxury and wealth for all requires a high-tech communist society: "It now remains for society, first, to extend this greater productivity, which is limited to certain industries, and to apply it to the general good. But it is evident that to utilize this high productivity of labour, so as to guarantee well-being to all, society must itself take possession of all means of production" $(1892 / 2012,88)$.

Murray Bookchin in the 1960s argued that we "of this century have finally opened the prospect of material abundance for all to enjoy - a sufficiency in the means of life without the need for grinding, day-to-day toil" $(1986,12)$. Liberatory technologies enable a "post-scarcity society", where "we can begin to provide food, shelter, garments, and a broad spectrum of luxuries without devouring the precious time of humanity and without dissipating its invaluable reservoir of creative energy in mindless labor" (12). Bookchin reminds us that not all technologies are liberating. Technologies need to be combined with and shaped by environmentalism and communalism. Bookchin argues for an "ecological approach to technology that takes the form of ensembles of productive units, energized by solar and windpower units" (46).

The list of theorists of socialist technology could be continued with names such as Herbert Marcuse (post-technology), Erich Fromm (humanised technology), Ivan Illich 
(convivial technologies), André Gorz (post-industrial socialism), Ernst Bloch (alliance technology), etc. Luxury communism is a new discovery for - but not by - Aaron Bastani, but relatively old hat in the history of the radical theory of technology and society. Communist theory needs proper engagement with this history.

Fully Automated Luxury Communism is, despite its tendencies of idealist utopianism and historical blindness, good food for thought about the foundations of communism.

\subsection{Socialism and Communication}

\subsubsection{Alienated and Socialist Culture}

Given that socialist society sublates the economy, politics and culture, new relations of communication also emerge in such a society. The way humans think, work, live and communicate changes in such a society. Table 3 opposes knowledge and communication's roles in alienated societies to their roles in socialist society.

In a class society, knowledge and communication are privately controlled and owned by the few as private property, whereas in a socialist society knowledge and communication technologies are gifts and common goods that are collectively produced and owned. If one looks at the way that contemporary media corporations are run, then one sees that the decisions are made by a small class of CEOs and managers who control these companies' decision-making processes in a dictatorial manner. Privately owned companies are economic dictatorships. In contrast, socialist politics implies that organisations in the culture and communication industry should not only be owned by their workers, but should also have democratic decision-making structures, where everyone working in the organisation or affected by it can participate. While alienated cultural systems produce ideologies and reputational hierarchies, socialist culture creates togetherness, respect for all, recognition of all, and unity in diversity of identities and lifestyles.

\begin{tabular}{|l|l|l|}
\hline & Alienated Society & Socialist Society \\
\hline Economic system & $\begin{array}{l}\text { Knowledge and commu- } \\
\text { nication as commodities, } \\
\text { exploitation of } \\
\text { knowledge labour, } \\
\text { means of communica- } \\
\text { tion as private property }\end{array}$ & $\begin{array}{l}\text { Knowledge and commu- } \\
\text { nication(s) as commons, } \\
\text { co-ownership and co- } \\
\text { production in self-man- } \\
\text { aged knowledge-creat- } \\
\text { ing companies }\end{array}$ \\
\hline Political system & $\begin{array}{l}\text { Dictatorial control of } \\
\text { knowledge and commu- } \\
\text { nication processes }\end{array}$ & $\begin{array}{l}\text { Participatory knowledge } \\
\text { and democratic commu- } \\
\text { nication }\end{array}$ \\
\hline Cultural system & $\begin{array}{l}\text { Ideological knowledge } \\
\text { and communication } \\
\text { and commist knowledge } \\
\text { advances togetherness, } \\
\text { unity in diversity, and } \\
\text { recognition of all }\end{array}$ \\
\hline
\end{tabular}

Table 3: Alienated and socialist forms of knowledge and communication

\subsubsection{Public Service Media and Community Media}

In contemporary capitalism, we can already find forms of media and culture that operate outside and in opposition to capital accumulation. The two most important social 
communication forms operating outside of capital are public service media and community media. Both operate on a not-for-profit basis. The difference is that public service media are organised and financed with the help of state legislation. They are independent from capital and the state, but are organised based on laws that regulate their remit (such as creating public service content) and their funding (e.g. in the form of a licence fee). Community media are citizen media that are run and operated by citizens who act as citizen journalists and citizen media producers.

The political economist of communication Graham Murdock $(2011,18)$ argues that the three political-economic possibilities in the media and cultural sector are ownership by capital (the commodity form of communications), by the state (the public service form of communications) and by civil society (communications as gifts/commons).

Public service media tend to reject the logic of the commodity. They make use of state power for collecting licence fees or parts of taxes in order to fund their operations. Alternative, citizen and community media such as open channels, free radio stations, the alternative press, or alternative Internet platforms are run by civil society groups. They do not embrace but rather reject the commodity logic. They tend not to want to sell content, technologies and audiences. Given that they reject exchange-value, they have to look for other sources of funding if they want to exist within capitalism. Such sources are, for example, voluntary unpaid labour, state funding, donations, endowments from foundations, and so on. Table 4 presents a distinction between a) capitalist media, b) public service media, and c) community media. These media are respectively based on a) information commodities, b) information as public good, and c) information commons. Information is owned in specific ways and has a specific cultural role, in which it allows humans to inform themselves, communicate, and organise social systems.

\begin{tabular}{|l|l|l|l|}
\hline & Capitalist media & Public service media & $\begin{array}{l}\text { Community me- } \\
\text { dia }\end{array}$ \\
\hline $\begin{array}{l}\text { Economy } \\
\text { (owner- } \\
\text { ship) }\end{array}$ & Corporations & State institutions & Citizen-control \\
\hline $\begin{array}{l}\text { Culture } \\
\text { (public cir- } \\
\text { culation of } \\
\text { ideas) }\end{array}$ & $\begin{array}{l}\text { Content that ad- } \\
\text { dresses humans in } \\
\text { various social roles } \\
\text { and results in mean- } \\
\text { ing-making }\end{array}$ & $\begin{array}{l}\text { Content that addresses } \\
\text { humans in various so- } \\
\text { cial roles and results in } \\
\text { meaning-making }\end{array}$ & $\begin{array}{l}\text { Content that ad- } \\
\text { dresses humans } \\
\text { in various social } \\
\text { roles and results } \\
\text { in meaning-mak- } \\
\text { ing }\end{array}$ \\
\hline
\end{tabular}

Table 4: Three political economies of information

The Slovenian critical media and communication scholar Slavko Splichal provides a concise definition of public service media: "In normative terms, public service media must be a service of the public, by the public, and for the public. It is a service of the public because it is financed by it and should be owned by it. It ought to be a service by the public - not only financed and controlled, but also produced by it. It must be a service for the public - but also for the government and other powers acting in the public sphere. In sum, public service media ought to become 'a cornerstone of democracy"' $(2007,255)$. Community media "is usually run on a not-for-profit basis and provides community members with an opportunity to participate in the production process" (Rennie 2006, 3), and has democratic governance structures. 
There is a tension and contradiction between public service and community media on the one hand and capitalist media on the other hand. Capitalism is expansive, imperialist and colonising - it tries to subsume everything under the commodity form and to destroy realms of life that do not adhere to the commodity logic. It can therefore be difficult for public service media and community media to exist in capitalism. Community media are, in capitalism, often based on voluntary, self-exploitative, unpaid or lowpaid labour. The history of alternative and community media is a history of self-determined but precarious labour and resource precarity. Such media tend to lack resources. Although alternative media represent common communications that transcend capitalism they lack the capital of the common needed for effectively challenging capitalist communication corporations. Culture, information and other goods and services can be de-commodified by social struggles and thereby turned into public or common goods. The more the logic of the commodity asserts itself, the more difficult is the existence and survival of public service media and community media. The more this logic is constricted, the more these alternative forms of organisation can flourish. In socialist society, there are no capitalist media, and information and culture have no commodity form.

Marx spoke about the importance of alternative, non-capitalist ways of organising the media. He writes that the "primary freedom" of the media "lies in not being a trade" (1842, 175, emphasis in original). Marx feared that the capitalist control of communications limited the freedom of speech and expression and colonised the public sphere. In the Manifesto of the Communist Party, Marx and Engels say that one of the political measures that communists aim at implementing is the "[ce]ntralisation of the means of communication and transport in the hands of the State" (Marx and Engels 1848, 505).

In the 20th century, many states held monopolies over telecommunications, broadcasting networks, railways, and the postal service. These are large infrastructures of communication. Organising them as public services enables fair, universal, affordable access. Today, there is a need for public service Internet platforms, such as a public service YouTube run by a network of public service companies, in order to challenge the monopolies of the digital giants Google, Facebook, Twitter, etc. Alternatives to communication services that store and process lots of personal data, such as Facebook, should be organised as self-managed community platforms because too much involvement by the state poses a certain danger of state surveillance potentials directed towards citizens. The same can be said of the press: self-managed newspapers are preferable to newspapers owned and operated as public services by institutions that are located close to the state. Public service media should also have news departments where independent journalists work. It is important that public service media are truly independent from the state, economic forces, and ideological forces.

\subsubsection{Rosa Luxemburg: The Freedom of the Press in Socialist Society}

Immediately after the 1917 October Revolution, the Bolsheviks set up the Revolutionary Press Tribunal, which had the power to censor or suspend publications and to deprive those responsible for them of their liberties, deporting them from Russia in cases where the Tribunal found that "crimes and offences [...] against the national through the use of the press" were committed (Lenin 1917a, 206). The freedom of the press was abolished.

Rosa Luxemburg on the one hand supported the need to replace the Czarist regime by a socialist society and on the other hand stresses the need for the democratic character of such a society. She commented that: 
Freedom only for the supporters of the government, only for the members of one party - however numerous they may be - is no freedom at all. Freedom is always and exclusively freedom for the one who thinks differently. Not because of any fanatical concept of 'justice' but because all that is instructive, wholesome and purifying in political freedom depends on this essential characteristic, and its effectiveness vanishes when 'freedom' becomes a special privilege" (Luxemburg 1918, 69).

Luxemburg criticised the curtailment of the freedom of expression in Russia under Lenin. She stressed that "universal suffrage, freedom of press and assemblage" and "the whole apparatus of the basic democratic liberties of the people" constitute the "right of self-determination" $(1918,48)$. Luxemburg spoke of "freedom of the press, the rights of association and assembly" as "the most important democratic guarantees of a healthy public" (66). Without "a free and untrammelled press, without the unlimited right of association and assemblage, the rule of the broad mass of the people is entirely unthinkable" (67).

A democratic socialist society needs to guarantee the freedom of expression, assembly, association and the press. Corporate media monopolies have to be dissolved by expropriating the capital of the owners and handing over the ownership of these organisations (including publishing technologies) to workers and citizens. In such a society, groups of citizens need to have the right and the technological and organisational opportunity to create their own media, collectively owned and operating as selfmanaged companies that are not operated for profit, pursuing the goals of informing and educating. The socialist public does not consist of state-controlled media, but a vivid public sphere that operates as a multitude of public service media organisations and self-managed media organisations.

\subsubsection{Democratic Communications}

In his book Communications, Raymond Williams (1976, 130-137) distinguishes between authoritarian, paternal, commercial and democratic communication systems (communications). The first three communication systems are political, cultural and commercial expressions of instrumental reason. Authoritarian communications involve state control, manipulation and censorship of the media. The "purpose of communication is to protect, maintain, or advance a social order based on minority power" (1976, 131). Paternal communications are authoritarian communications "with a conscience: that is to say, with values and purposes beyond the maintenance of its own power" (131). In such communication systems, there is ideological control that aims to impose certain moral values on audiences. The controllers of paternal communication systems assume that specific morals are good for citizens and that the latter are too silly to understand the world. In commercial communications, there is commercial control: "Anything can be said, provided that you can afford to say it and that you can say it profitably" (133). All three forms are instrumental: they instrumentalise communications as tools for control and domination.

In contrast, democratic communications are, for Williams, based on co-operative rationality. Such media systems are based on the freedom to speak and the free choice of what to receive. Such communications are a "means of participation and of common discussion" $(1976,134)$. Williams argues for a cultural democracy that combines public service media, cultural co-operatives and local media. ${ }^{3}$ Such a democracy establishes

\footnotetext{
${ }^{3}$ See also Williams (1983, 65-72).
} 
"new kinds of communal, cooperative and collective institutions" $(1983,123)$. The core of Williams' proposal is "that public ownership of the basic means of production [the means of communication and cultural production] should be combined with leasing their use to self-managing groups, to secure maximum variety of style and political opinion and to ensure against any bureaucratic control" $(1979,370)$ : "The idea of public service must be detached from the idea of public monopoly, yet remain public service in the true sense" of public service content $(1976,134)$. Instrumental and co-operative media are contradictory forces. Only cultural forms of class struggle can drive back the capitalist colonisation of communications. Democratic communications are the dominant form of communication in a socialist society, in which "the basic cultural skills are made widely available, and the channels of communication widened and cleared, as much as possible" (1958/1983, 283).

\subsubsection{Socialist Journalism}

Béla Fogarasi (1891-1959) was a Hungarian philosopher. In his essay "The Tasks of the Communist Press"), Fogarasi (1921/1983) distinguishes between the capitalist and the socialist press. He argues that the capitalist press is "an ideological weapon in the class struggle" $(1921 / 1983,149)$ utilised by the bourgeoisie in order to "dominate the ideology of the ensemble of classes" (149): "What the capitalist press seeks is to shape the structure of the reader's consciousness in such a way that he will be perpetually unable to distinguish between true and false, to relate causes and effects, to place individual facts in their total context, to rationally integrate new knowledge into his perspective" (150). Fogarasi implicitly applies Georg Lukács' (1971) critique of reified consciousness to the capitalist press. In the capitalist press, the focus is often not on the dialectic of totality, particularity and individuality, but merely on individual, isolated pieces of news. According to Fogarasi, strategies of the capitalist press include reporting a multitude of isolated facts that quench the readers' thirst for knowledge; de-politicisation and sensationalism that work "systematically in the service of such diversion" (1921/1983, 150); and pseudo-objectivity. In contrast, the socialist press tries to advance the consciousness of society as totality and of the relation of single events with each other and broader contexts, the unmasking of the capitalist press, and the participation of readers as producers of reports (1921/1983, 151-153).

Fogarasi not only applied Lukács' (1971) concepts of reification and the totality to journalism, but also in 1921 anticipated Walter Benjamin's $(1934,777)$ idea of turning "consumers [...] into producers" and "readers or spectators into collaborators" as well as Bertolt Brecht's $(1932,42)$ idea of a radio that lets "the listener speak as well as hear". Fogarasi's essay also anticipates some elements of Edward Herman and Noam Chomsky's (1988) propaganda model. Herman and Chomsky identified some dimensions of how bourgeois journalism creates reified presentations of reality. Corporate media use five filters that limit the freedom of the media: corporate ownership and monopolies; advertising; selective sources; effects of lobbying; and ideology. ${ }^{4}$

\subsubsection{Digital Commons}

Computers and computer networks enable new ways of organising information, communication and co-operation. Given that computing has become a central resource in modern society, the use of computers for organising cognition, communication and cooperation has become a human need. Humans have certain cognitive needs (such as

${ }^{4}$ For discussions of the relevance of this propaganda model today, see the contributions in Pedro-Carañana, Broudy and Klaehn (2018). 
being loved and recognised), communicative needs (such as friendships and community) and co-operative needs (such as working together with others in order to achieve common goals) in all types of society. In a digital and information society, computers are a vital means for realising such needs. But given that computers are always used in societal contexts, computer use as such does not necessarily foster the good life, but can also contribute to damaging human lives.

Digital capitalism at the same time deepens exploitation and creates new foundations for autonomous realms that transcend the logic of capitalism. There is an antagonism between the networked productive forces and the class relations of digital production. This antagonism is also an antagonism between digital labour and digital capital and between digital gifts and digital commodities.

Table 5 provides a summary overview of the dimensions of the digital commons. The typology presented in Table 5 is structured along the three realms of society (economy, politics, culture), which allows us to distinguish between three types of commons and three types of digital commons. The commons are the Aristotelian-Marxian vision of a good society. They form the essence of society, which means that the digital commons are part of digital society's essence. For Hegel and Marx, the essence is often hidden behind false appearances, and that actuality means the correspondence of essence and appearance. One needs to distinguish between the essence of digital society and the false appearance and existence of digital society as digital class society and digital capitalism. Class society is the false condition of society-in-general. Digital class society is the false condition of digital society. A critical theory of the digital commons needs to have not just a vision of a good digital society, but also a critique of digital capitalism and digital alienation. Table 5 therefore also features two columns that outline dimensions of alienation-in-general and digital alienation.

\begin{tabular}{|c|c|c|c|c|}
\hline & Commons in society & Digital commons & $\begin{array}{l}\text { Lack of com- } \\
\text { mon control in } \\
\text { society (aliena- } \\
\text { tion) }\end{array}$ & $\begin{array}{l}\text { Lack of com- } \\
\text { mon control of } \\
\text { digital society } \\
\text { (digital aliena- } \\
\text { tion) }\end{array}$ \\
\hline Economy & $\begin{array}{l}\text { Economic commons: } \\
\text { wealth and self- } \\
\text { fulfilment for all }\end{array}$ & $\begin{array}{l}\text { Economic digital } \\
\text { commons: network } \\
\text { access for everyone, } \\
\text { community is in con- } \\
\text { trol of technology, } \\
\text { digital resources as } \\
\text { common goods }\end{array}$ & Private property & $\begin{array}{l}\text { Digital } \\
\text { commodities, } \\
\text { digital resources } \\
\text { as private } \\
\text { property }\end{array}$ \\
\hline Politics & $\begin{array}{l}\text { Political commons: } \\
\text { participation and } \\
\text { democracy in decision- } \\
\text { making }\end{array}$ & $\begin{array}{l}\text { Political digital com- } \\
\text { mons: common deci- } \\
\text { sion making/govern- } \\
\text { ance of ICTs }\end{array}$ & Dictatorship & $\begin{array}{l}\text { Dictatorial } \\
\text { governance and } \\
\text { control of ICTs }\end{array}$ \\
\hline Culture & $\begin{array}{l}\text { Cultural commons: } \\
\text { voice and recognition } \\
\text { of all }\end{array}$ & $\begin{array}{l}\text { Cultural digital com- } \\
\text { mons: use of ICTs } \\
\text { for fostering learning, } \\
\text { recognition and com- } \\
\text { munity activities }\end{array}$ & Ideology & $\begin{array}{l}\text { Digital ideology: } \\
\text { Ideologies of and } \\
\text { on the Internet }\end{array}$ \\
\hline
\end{tabular}

Table 5: Three dimensions of the digital commons 


\section{Conclusion: Ten Principles of Communicative/Digital Socialist Politics}

Communism and socialism are often associated with Stalin and Mao, whose ideas and societies had little to do with Marx and Engels' democratic vision of society. Socialism is a framework for society and a movement towards a good society for all.

Common property, computerised high technology, a post-scarcity society that creates wealth and luxury for all, well-rounded individuals, distribution according to human needs, participatory governance, a common culture, and internationalism are some of the aspects of socialist society.

Capitalism is shaped by the antagonism between productive forces and relations of production, which takes on new relevance in the age of networked productive forces.

Commons-based communication is an alternative to alienated communication. Public service media and community media are two not-for-profit models. They face specific contradictions in capitalist society. In socialist society, communication and culture take on a common character. Socialist means of communication feature common control, common decision-making, and a common culture. Socialist communications are truly democratic communications.

Socialist politics should engage with and not ignore communication politics. A good society needs to be a socialist and commons-based society, which includes the perspectives of communicative and digital socialism. Socialism is a political-economic movement that has its economic foundations in socialised aspects of the economy already within capitalism and has its political foundations in class struggles against capitalism and for socialism. Socialist politics should think of both public services and civil society as the realms from where alternatives emerge.

There are ten principles of communicative/digital socialist politics:

\section{Techno-dialectics:}

Socialist communication politics avoids techno-optimism/techno-euphoria as well as techno-pessimism. Instead, it asks: How can technology and society be shaped in manners that benefit all humans, workers and citizens and develop the positive potentials of society and humanity?

\section{Radical reformist communication politics:}

Socialist communication politics is neither reactionary reformism that bows to bourgeois interests nor utopian revolutionary romanticism. It advances a dialectic of reform and revolution (radical reformism). It struggles for measures that simultaneously bring about immediate improvements and advance the possibilities and resourcing of alternative non-capitalist projects, and it struggles for communicative/digital socialism. Socialist communication politics operates both at the level of political parties and social movements. It brings about co-operations of both in the form of a politically co-operating multitude.

\section{United class struggles of communication workers:}

Communication corporations exploit different kinds of workers. Alternatives to communicative capitalism can only emerge out of class struggles. Socialist communication politics supports the digital and communication workers of the world in uniting. In order to make this struggle effective, we need national and international trade unions that unite all the different communication workers across branches, occupations, countries, corporations, cultures, etc. in one union of communication workers. 
The class struggles of communication workers are often fragmented. In order to fight global capital in general and global communication capital in particular, communication workers of the world need to unite, avoid and fight the ideologies of fascism, nationalism, racism and xenophobia wherever they appear (including in communication networks), and develop strategies of international solidarity and joint struggles.

Capitalism exploits different kinds of workers, including unwaged workers who produce the commons and social relations. Unpaid workers' interests are not best served by the demand for an individualised wage, but by the demand for a social wage in the form of a corporation-tax-funded, redistributive basic income guarantee.

\section{Collective control of the means of communication as means of production:} In digital and communicative capitalism, communication technologies such as computers, apps, software, hardware, data, and content are means of production. Capital controls and commodifies communication resources. Where these resources matter in the context of labour, it is an important political task that workers demand, struggle for and obtain the collective control of the means of communication as means of economic production.

\section{Break-up of communication monopolies:}

Corporate communication monopolies centralise economic power and are a threat to democracy. Socialist communication politics argues for and works towards breaking up corporate monopolies. It neither favours national over international capital (or viceversa) nor small or medium-size capital over large capital (or vice-versa), but no capital, public goods and common goods instead of capital.

\section{Privacy friendliness, socialist privacy:}

Public and commons-based communications should respect users' privacy and minimise their economic and political surveillance as well as other forms of surveillance. Personal data collection and storage should be minimised to the data that is absolutely necessary. The surveillance capacities of the state should be re-directed from the constant surveillance of citizens towards the policing of tax-avoiding corporations and white-collar crime. An important task and demand is to criticise and demand abolishment of the surveillance of workers and the mass surveillance of citizens. Socialist privacy means that data collection is minimised, information and communication systems are designed in a privacy-friendly manner, and surveillance is directed against powerful corporations in order to increase the transparency of their economic and financial operations.

\section{Public service media and communications co-operatives:}

The struggle for socialism needs to be fought in the territories of public services, the state, and civil society. The political Left should struggle for three forms of collective communication services: those that are publicly operated or enabled by the state, those that are collective-owned by worker co-operatives, and those that are organised as public/commons-partnerships (partnerships of public institutions and civil society).

Services that involve lots of sensitive personal data (such as political opinions) ought not to be operated by the state in order to reduce the risk of state surveillance of political opinions. Services that involve the need for high storage capacity can best be operated by public institutions and public service media. Practically speaking this means, for example, that there should be a public service YouTube and a civil-society- 
based Facebook platform co-operative. The state should legally and economically enable public service media to create digital public services and digital public service corporations. Newspapers should best be operated as non-profit, advertising-free, selfmanaged companies. Press subsidies funded out of taxation should only be given to non-profit, advertising-free, non-tabloid newspapers. Alternative funding mechanisms for public service and commons-based non-profit, non-commercial media should be sought. They include, for example: corporation taxes; taxing online advertising and advertising in general; licence and media fees paid by users of public service media; donation models; a digital service tax for large transnational digital corporations; and so on.

\section{Democratic, public sphere media:}

The logic of communicative capitalism and the commodity form favours superficiality, high-speed flows of information and news, the personalisation of politics, tabloidisation, one-dimensionality, and partiality in the interest of the bourgeoisie. Alternatives decelerate information flows (slow media), foster informed political debate and learning through collective creation, and participation in spaces of public communication that are ad-free, non-commercial, and not-for-profit. Such spaces enable both professional media and citizen media as well as the dialectical fusion of both. Socialist communication politics supports the creation and sustenance of media that have the potential to help to advance critical, anti-ideological thought by fostering engagement with content that stimulates critical, dialectical, anti-ideological thought and debate, and opposes classist, fascist, racist, xenophobic and sexist discourse.

\section{Political and protest communication:}

Communication technologies are not the cause of protests, rebellions and revolutions, but they are an important part of protest communication. Socialist communication politics seeks to use communication technologies for spreading socialist politics to a broad public. Wherever possible, it supports the development and use of non-commercial, non-profit media for organisation and public communication. It aims to avoid creating 'alternative ghettos' of resource-poor alternative media that are based on precarious labour. For this purpose, one requires a politics that focuses on channelling resources towards alternative media.

Political education in schools and other educational institutions is also an aspect of political communication. Political education will enable humans to critically reflect on society as well as engage in complex, dialectical and independent thinking.

\section{Self-managed, democratic governance:}

Socialist communication politics supports, believes in the necessity of and advances the democratic and participatory governance of media organisations, so that the workers producing in these companies and representatives of everyday citizens affected by these media's operations participate in the decision-making process.

The ethics of the commons is political because it requires praxis and the struggle for alternatives to capitalism in order to make humans and society flourish and realise their potentials. The society of the commons transcends capitalism because it goes beyond the latter. Love is the principle of the society of the commons.

\section{References}

Ali, Tariq. 2009. The Idea of Communism. London: Seagull.

Badiou, Alain. 2015. The Communist Hypothesis. London: Verso. 
Bastani, Aaron. 2019. Fully Automated Luxury Communism. London: Verso.

Bauwens, Michel and Vasilis Kostakis. 2014. From the Communism of Capital to Capital for the Commons: Towards Open Co-Operativism. tripleC: Communication, Capitalism \& Critique 12 (1): 356-361.

Benjamin, Walter. 1934. The Author as Producer. In Walter Benjamin: Selected Writings Volume 2, Part 2, 1931-1934, 768-782. Cambridge, MA: Belknap Press.

Beverungen, Armin, Anna-Maria Murtola and Gregory Schwartz. 2013. The Communism of Capital? Ephemera 13 (3): 483-495.

Bookchin, Murray. 1986. Post-Scarcity Anarchism. Montreal: Black Rose Books.

Brecht, Bertolt. 1932. The Radio as a Communications Apparatus. In Bertolt Brecht on Film \& Radio, 41-46. London: Bloomsbury.

Dean, Jodi. 2012. The Communist Horizon. London: Verso.

Douzinas, Costas and Slavoj Žižek, eds. 2010. The Idea of Communism. London: Verso.

Dyer-Witheford, Nick. 2014. The Global Worker and the Digital Front. In Critique, Social Media and the Information Society, edited by Christian Fuchs and Marisol Sandoval, 165178. New York: Routledge.

Engels, Friedrich. 1847a. Draft of a Communist Confession of Faith. In MECW Volume 6, 96103. London: Lawrence \& Wishart.

Engels, Friedrich. 1847b. Principles of Communism. In MECW Volume 6, 341-357. London: Lawrence \& Wishart.

Engels, Friedrich. 1845a. Speeches in Elberfeld. In MECW Volume 4, 243-255 London: Lawrence \& Wishart.

Engels, Friedrich. 1845b. The Festival of Nations in London (To Celebrate the Establishment of the French Republic, Sep 22, 1792). In MECW Volume 6, 3-14. London: Lawrence \& Wishart.

Fogarasi, Adalbert. 1921/1983. The Tasks of the Communist Press. In Communication and Class Struggle 2: Liberation, Socialism, edited by Armand Mattelart and Seth Siegelaub, 149-153. New York: IMMRC.

Fromm, Erich. 1961/2003. Marx's Concept of Man. London: Continuum.

Fuchs, Christian. 2020a. Communication and Capitalism: A Critical Theory. London: University of Westminster Press.

Fuchs, Christian. 2020b. Marxism: Karl Marx's Fifteen Key Concepts for Cultural and Communication Studies. New York: Routledge.

Fuchs, Christian 2020c. Nationalism on the Internet: Critical Theory and Ideology in the Age of Social Media and Fake News. New York: Routledge.

Fuchs, Christian. 2017. Raymond Williams' Communicative Materialism. European Journal of Cultural Studies 20 (6): 744-762.

Fuchs, Christian. 2016. Georg Lukács as a Communications Scholar: Cultural and Digital Labour in the Context of Lukács' Ontology of Social Being. Media, Culture \& Society 38 (4): 506-524.

Hardt, Michael and Antonio Negri. 2017. Assembly. Oxford: Oxford University Press.

Hardt, Michael and Antonio Negri. 2009. Commonwealth. Cambridge, MA: Harvard University Press.

Herman, Edward S. and Noam Chomsky. 1988. Manufacturing Consent: The Political Economy of the Mass Media. London: Vintage.

Honneth, Axel. 2017. The Idea of Socialism: Towards a Renewal. Cambridge: Polity.

Kropotkin, Peter. 1892/2012. The Conquest of Bread. In The Conquest of Bread and Other Writings, edited by Marshall S. Shatz, 1-199. Cambridge: Cambridge University Press.

Lenin, Vladimir I. 1917a. On the Revolutionary Press Tribunal. In Lenin About the Press, 206-207. London: Journeyman Press.

Lenin, Vladimir I. 1917b. The State and Revolution. The Marxist Theory of the State and the Tasks of the Proletariat in the Revolution. In Lenin Collected Works Volume 25, 385-497. Moscow: Progress. 
Lukács, Georg. 1971. History and Class Consciousness. London: Merlin.

Lund, Arwid. 2017. Wikipedia, Work and Capitalism. A Realm of Freedom? Cham: Palgrave Macmillan.

Luxemburg, Rosa. 2008. The Essential Rosa Luxemburg. Chicago, IL: Haymarket Books.

Luxemburg, Rosa. 1925. Introduction to Political Economy. In The Complete Works of Rosa Luxemburg. Volume I: Economic Writings 1, ed. Peter Hudis, 89-300. London: Verso.

Luxemburg, Rosa. 1918. The Russian Revolution. In The Russian Revolution and Leninism or Marxism?, 25-80. Ann Arbor, Ml: The University of Michigan Press.

Marazzi, Christian. 2010. Il comunismo del capitale. Verona: Ombre Corte.

Marx, Karl. 1894. Capital Volume Three. London: Penguin.

Marx, Karl. 1885. Capital Volume Two. London: Penguin.

Marx, Karl. 1875. Critique of the Gotha Programme. In MECW Volume 24, 75-99. London: Lawrence \& Wishart.

Marx, Karl. 1867. Capital Volume One. London: Penguin.

Marx, Karl. 1857/1858. Grundrisse: Foundations of the Critique of Political Economy. London: Penguin.

Marx, Karl. 1850. The Class Struggles in France, 1848 to 1850. In MECW Volume 10, 45145. London: Lawrence \& Wishart.

Marx, Karl. 1844. Economic and Philosophic Manuscripts of 1844. In MECW Volume 3, 229346. London: Lawrence \& Wishart.

Marx, Karl. 1843. Letters from the Deutsch-Französische Jahrbücher. In MECW Volume 3, 133-145. London: Lawrence \& Wishart.

Marx, Karl. 1842. Proceedings of the Sixth Rhine Province Assembly. First Article. Debates on Freedom of the Press and Publication of the Proceedings of the Assembly of the Estates. In MECW Volume 1, 132-181. London: Lawrence \& Wishart.

Marx, Karl and Friedrich Engels. 1848. Manifesto of the Communist Party. In MECW Volume 6, 477-519. London: Lawrence \& Wishart.

Marx, Karl and Friedrich Engels. 1845/1846. The German Ideology. Critique of Modern German Philosophy According to Its Representatives Feuerbach, B. Bauer and Stirner, and of German Socialism According to Its Various Prophets. In MECW Volume 5, 15-539. London: Lawrence \& Wishart.

Murdock, Graham. 2011. Political Economies as Moral Economies: Commodities, Gifts, and Public Goods. In The Handbook of Political Economy of Communications, edited by Janet Wasko, Graham Murdock, and Helena Sousa, 13-40. Malden, MA: Wiley-Blackwell.

Pedro-Carañana, Joan, Daniel Broudy and Jeffery Klaehn, eds. 2018. The Propaganda Model Today: Filtering Perception and Awareness. London: University of Westminster Press.

Rennie, Ellie. 2006. Community Media: A Global Introduction. Lanham, MD: Rowman \& Littlefield.

Rosdolsky, Roman. 1977. The Making of Marx's "Capital”. London: Pluto Press.

Splichal, Slavko. 2007. Does History Matter? Grasping the Idea of Public Service at its Roots. In From Public Service Broadcasting to Public Service Media. RIPE@2007, edited by Gregory Ferrell Lowe and Jo Bardoel, 237-256. Gothenburg: Nordicom.

Sunkara, Bhaskar. 2019. The Socialist Manifesto: The Case for Radical Politics in An Era of Extreme Inequality. London: Verso.

Virno, Paolo. 2004. Grammar of the Multitude. Los Angeles, CA: Semiotext(e).

Williams, Raymond. 1983. Towards 2000. London: Chatto \& Windus.

Williams, Raymond. 1958/1983. Culture \& Society: 1780-1950. New York: Columbia University Press.

Williams, Raymond. 1979. Politics and Letters: Interviews with New Left Review. London: Verso.

Williams, Raymond. 1976. Communications. Harmondsworth: Penguin.

Žižek, Slavoj, ed. 2013. The Idea of Communism 2. London: Verso. 
Žižek, Slavoj, 2010. How to Begin From the Beginning. In The Idea of Communism, edited by Costas Douzinas and Slavoj Žižek, 209-226. London: Verso.

Žižek, Slavoj and Alex Taek-Gwang Lee, eds. 2016. The Idea of Communism 3. London: Verso.

\section{About the Author}

Christian Fuchs

Christian Fuchs is co-editor of tripleC: Communication, Capitalism \& Critique, a critical theorist of society and communication, and author of many books and articles. @fuchschristian; http://fuchs.uti.at 